\title{
Reimagining socio-economic well-being through the integration of Arthashastra's economic treatise and Madhva's philosophical notion on social cohesion
}

\begin{tabular}{|c|c|}
\hline \multicolumn{2}{|c|}{$\begin{array}{l}\text { Authors: } \\
\text { Mathias Yuvan Shunmugam }{ }^{1} \text { (D) } \\
\text { Maniraj Sukdaven }^{1} \text { (D) }\end{array}$} \\
\hline \multicolumn{2}{|c|}{$\begin{array}{l}\text { Affiliations: } \\
{ }^{1} \text { Department of Religious } \\
\text { Studies, Faculty of } \\
\text { Theology and Religion, } \\
\text { University of Pretoria, } \\
\text { Pretoria, South Africa }\end{array}$} \\
\hline \multicolumn{2}{|c|}{$\begin{array}{l}\text { Corresponding author: } \\
\text { Mathias Yuvan Shunmugam, } \\
\text { ysshunmugam@gmail.com }\end{array}$} \\
\hline \multicolumn{2}{|c|}{$\begin{array}{l}\text { Dates: } \\
\text { Received: } 27 \text { Sept. } 2021 \\
\text { Accepted: } 21 \text { Jan. } 2022 \\
\text { Published: } 22 \text { Feb. } 2022\end{array}$} \\
\hline \multicolumn{2}{|c|}{$\begin{array}{l}\text { How to cite this article: } \\
\text { Shunmugam, M.Y. \& } \\
\text { Sukdaven, M., 2022, } \\
\text { 'Reimagining socio-economic } \\
\text { well-being through the } \\
\text { integration of Arthashastra's } \\
\text { economic treatise and } \\
\text { Madhva's philosophical } \\
\text { notion on social cohesion', } \\
\text { Theologia Viatorum } \\
46(1), \text { a139. https://doi. } \\
\text { org/10.4102/tv.v46i1.139 }\end{array}$} \\
\hline \multicolumn{2}{|c|}{$\begin{array}{l}\text { Copyright: } \\
\text { (C) 2022. The Authors. } \\
\text { Licensee: AOSIS. This } \\
\text { is licensed under the } \\
\text { Creative Commons } \\
\text { Attribution License. }\end{array}$} \\
\hline \multicolumn{2}{|l|}{ Read online: } \\
\hline 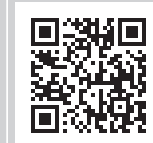 & $\begin{array}{l}\text { Scan this QR } \\
\text { code with your } \\
\text { smart phone or } \\
\text { mobile device } \\
\text { to read online. }\end{array}$ \\
\hline
\end{tabular}

\begin{abstract}
The current coronavirus disease 2019 (COVID-19) pandemic that has ravaged glocal societies of both developed and developing countries, has once again shown that there are some phenomena that are no respecters of societies. This is clearly observed in the most recent COVID-19 global statistics, where the most advanced country in the world has the greatest number of infections and deaths. Globally, there are 171.5 million COVID-19 cases, 153.7 million recoveries and 3.6 million deaths (worldmeters.info/coronavirus accessed 01 June 2021). Not only has COVID-19 devastated both developed and developing countries, but has also demonstrated the widening gulf between the rich and the poor. The Minority World were able to secure millions of vaccine doses for their citizens, while the Majority World had to wait in line. We have also witnessed an uprising recently (July 2021) in two of South African provinces of social dissolution where socio-economic and racial tension resulted in a number of deaths. It is within this context that this study aimed to examine how the integration of Arthashastra's economic treatise and Madhva's philosophical notion on social cohesion, can contribute to a just socio-economic society. Even though Arthashastra's economic treatise and Madhva's philosophical notion of social cohesion are common within Hinduism, and more specifically related to India, the global community will benefit from implementing the salient features from it for application in their contexts.
\end{abstract}

Keywords:. theology; religion; Hinduism; Madhva; socio-economic; social cohesion; philosophy; Arthashastra.

\section{Introduction}

According to the statistics of the worldwide coronavirus disease 2019 (COVID-19) report, the five most affected countries presently are as follows: (1) United States of America- 34.1 million cases and 609.7 thousand deaths, (2) India - 28.2 million cases and 331.9 thousand deaths, (3) Brazil - 16.5 million cases and 462.9 thousand deaths, (4) France -5.67 million cases and 109.5 thousand deaths, and (5) Turkey -5.2 million cases and 47.5 thousand deaths. Closer to home, here in South Africa (SA) - 1.7 million cases and 56.5 thousand deaths.

The above-mentioned statistical reports reflect an example of the devastation that COVID-19 has caused. From these statistics, it is clear that COVID-19 has inflicted a toll on both Majority and Minority worlds. The Minority world, being much wealthier than the Majority world, were able to secure vast amounts of COVID-19 vaccinations for their citizens. The Majority world had to wait in line because they did not have the financial muscle to compete with the Minority world. As this is only an example of how unequal the global society is, the authors of this article wish to put forward a proposal of how economic policies can be implemented that will assist the global community in developing an equal society and, in doing so, also promote social cohesion among citizens of the global community. In proposing this, the economic treatise of Arthashastra and the social cohesion ideals of Madhva are considered.

We will firstly examine the contribution that Arthashastra treatise makes to economic policies and then consider the philosophical ideals of social cohesion that Madhva addresses through his philosophy of Dvaita. Thereafter we will combine these two contributions to reimagine a just and socio-economic environment conducive to the establishment of an equitable society.

An important aspect of social cohesion is economic equality. Ritzen and Woolcock (2000:5) explain that the 'uprooting' of poverty and the addressal of economic developmental issues are pivotal for the construction of a socially cohesive society. 
Borisov and Vinogradov (2018:522) explain that social cohesion, while promoting economic development, aims to close the 'gap between the rich and the poor'. An important objective of social cohesion is the advocacy of economic equality, although this may be challenging for world economies to implement due to social and econometric factors. Without economic equality, social class systems form and prevent socially cohesive development. Therefore, the contribution of the political economy of Arthashastra and the social cohesion philosophy of Dvaita together will afford us to present an answer to the socio-economic well-being of a nation.

\section{Arthashastra economic treatise}

The themes of the Arthashastra focus on ensuring economic development and social cohesion through well-structured management of state funds that centre on public welfare.

In Hinduism, the Purushartha refers to the objectives of Human life and is subdivided into Dharma (law), Artha (wealth), Kama (pleasure) and Moksha (salvation). Sharma (2008:70) explains: 'Dharma, Artha, Kama, and Moksa are the aims or goals of human life which man ought to strive for attaining it throughout his life, and in all births'. In this section we therefore reflect on the Arthashastra ${ }^{1}$ - as any discussion involving political economics will do well to mention this ancient text. Das (2012:vii) in the introduction to the book by Trautman (Arthashastra: The Science of Wealth), claims that the Arthashastra is 'the world's first manual in political economy'.

In accordance with the Purushartha, the Arthashastra focuses on guiding people towards upholding Dharma and Artha to allow for lawful, ethical, and righteous practices in the process of accumulating wealth. For reimagining socioeconomic wealth and integrating the Arthashastra's economic treatise with Madhva's philosophy, an introduction to the Arthashastra that touches on its historical context is necessary. The historical context and background aids in uncovering societal challenges that the Arthashastra sought to address, which in turn creates a clear identification of socially cohesive concepts within the Arthashastra. This further contributes to integrating the Arthashastra with Madhva's philosophy towards socio-economic well-being.

Hindu philosophy recognises the importance of Artha, wealth and possessions, in the daily lives of humankind. Due to the importance of Artha, the Hindu philosopher Chanakya ${ }^{2}$ wrote the Arthashastra around 300 BCE. The Arthashastra consists of 15 books, 150 chapters, 180 sections and 6000 slokas (poetic form). Chanakya was born in 375 BCE and was well known as the adviser to Chandragupta Maurya, who was the founder of the Mauryan empire. According to Waldauer, Zahka and Pal (1996:101), Chanakya wrote the Arthashastra as a 'primer for good rule by the king' so as 'to increase the monarch's wealth and that of his realm'.

1.Translated from Sanskrit meaning 'The science of material gain'.

2.Also known as Kautilya and Vishnugupta.
Boesche (2003:9) describes the Arthashastra as 'one of the greatest political books of the ancient world'. Echoing this sentiment, Sihag (2016:60) says that the Arthashastra focuses on teaching the 'peaceful enjoyment of prosperity for all people'. Boesche (2003:9) and Sihag (2016:60) describe the Arthashastra as a manual that centres on the socio-economic well-being for all people - establishing the Arthashastra as a valuable, contributing, text to the reimagining of socioeconomic well-being.

The Arthashastra is simply an economical treatise written by Chanakya with the aim of merging economics and politics for the social welfare and prosperity of people living in India; yet it is applicable to the global community today.

Tanwar (2014:32-35) notes that the Arthashastra covers the following themes, among others:

1. State welfare - The happiness of the king lies in the happiness of his subjects. As a result, the needs of the people must be a top priority for a ruler. According to the White Paper for Social Welfare by the South African government (1997), ${ }^{3}$ the goal of state/social welfare is to promote a humane, peaceful, developing, just society that upholds the basic human rights and promotes all people to participate in all spheres of life, i.e, creative expression, sport, social, economic, political, etc. Economic growth, employment, social development, and the addressal of economic and social disparities form the main focal points of state welfare. The Arthashastra containing teachings pertaining to state welfare (and the subsequent economic and social development) relates to Madhva's teachings on social cohesion, as both look toward the overall wellbeing of state citizens.

2. Good governance-successful governance relies on strong economic policies that ensure transparent administration and financial development. On the significance of good governance as a link between the Arthashastra and Madhva's philosophy on social cohesion, Kraipornsak (2018:93) defines good governance as: 'a key factor that plays [a] role in modern economic development'. Therefore, good governance is characterised by the administrative operations of an institution that advances economic and social development toward promoting overall wellbeing. Re-imagining socio-economic wellbeing depends on good governance for the success of economic wellbeing and equity.

3. Foreign trade - Tanwar (2014:34) states: 'Kautilya recognized that foreign trade in goods and services is a major vehicle for increasing state wealth'. Trade, import, and export are vital to economic stability and growth. According to Barker (1977:154), free, international trade stimulates substantial growth in the production of goods. By encouraging mass production of goods, foreign trade enables job opportunities and growth in a country's income. As a theme of the Arthashastra, foreign trade mirrors Madhva's philosophy on social cohesion by increasing economic growth (allowing for economic 3.https://www.gov.za/sites/default/files/gcis_document/201409/ whitepaperonsocialwelfare0.pdf 
cohesion) through improving productivity, expanding the market, and creating employment opportunities.

4. Taxation - Developing a rich treasury is vital to the survival of a kingdom. Tax should be regulated to ensure that it is for the benefit of people rather than a means of creating a rich elite. Discussions pertaining to economic growth and the re-imagining of socio-economic wellbeing requires mention of taxation. Macek (2014) explains:

When evaluating the impact of fiscal variables on economic growth, it is necessary to derive from the fact that taxation influences economic growth solely through its impact on individual growth variables. (p. 311)

Taxation as an important discussion point for economic wellbeing displays the Arthashastra's contribution to the discussion of re-imagining socio-economic wellbeing - as the Arthashastra covers themes that are relevant to the conversations of economic development and wellbeing in the current era.

5. Growth orientated public expenditure - Expenses made by the king should focus on public welfare and development. Countries that invest in education experience social development and growth on a faster scale as opposed to countries that make little investments towards education (Suwandaru 2021:1). Growth orientated public expenditure is characterised by governmental expenditures that focus on development sustainable economic and social development. Linked to good governance, growth orientated public expenditure allows for socio-economic wellbeing through concerns expressed by governmental structures toward a specific sector. As a result, funds are allocated for the development of that sector. Growth orientated public expenditure fits into the re-imagining of socio-economic wellbeing by stressing the importance of allocating funds toward growth-oriented activities such as technological and scientific innovation, employment opportunities, health care, and education (primary, secondary, and tertiary).

6. Infrastructure - Tanwar (2014) claims:

Kautilya considers infrastructure as very important for the state development and also very useful for promoting commercial and trade activities. He suggests that state should invest in transport infrastructure, especially roads so that foreign trade and commercial activities can be increased .... (pp. 34-35)

7. The United Nations Human Settlements Programme (2011) $)^{4}$ affirms:

A recent body of research confirms the importance of infrastructure service provision to sustainable development. The World Bank's (1994) World Development Report landmark study on infrastructure highlighted the critical role of infrastructure in the development process. (p. 9)

8. The sustainable development referred to is characterised by the creation of employment opportunities, ease of access,

4.https://unhabitat.org/sites/default/files/download-manager-files Infrastructure $\% 20$ for $\% 20$ Poverty $\% 20$ Reduction $\% 20$ and $\% 20$ Economic $\% 20$ Development $\% 20$ in $\% 20$ Africa.pdf linking different communities, improving environment conditions, and allowing trade flows within and across borders ${ }^{5}$. In promoting sustainable development, infrastructure as a theme of the Arthashastra relates to Madhva's philosophy on social cohesion in encouraging the re-imagination of socio-economic wellbeing. This is evident in the vital role that infrastructure plays toward sustainable development.

The above-mentioned themes of the Arthashastra focus on ensuring economic development and social cohesion through well-structured management of state funds that centres on public welfare. These themes are important to this discussion as they form the foundation of what socioeconomic well-being entails. For the integration of the Arthashastra's economic treatise with Madhva's philosophy, the above-mentioned themes are required as they guide the researcher through Madhva's philosophy by displaying the themes that are relevant to socioeconomic well-being.

While heeding to the contribution made by the Arthashastra on economics and social cohesion, Rajeev (2012) states that:

People who have built a state by social-cohesion, they built it for security and welfare. Welfare of citizens is the priority of the king. He should do his best efforts for welfare... By it as well as economy and work can be provided. (p. 14)

Thus, the Arthashastra contributes significantly to the discussion on economics and socially cohesive governance which should be seriously considered by politicians and economists of any country. When this socio-economic structure is coupled with Madhva's philosophy of social cohesion, we have an added incentive to offer a successful social-economic well-being for society at large.

To assess Madhva's contribution to economics and social cohesion, his literary work requires an engagement with the six themes of the Arthashastra. Although Madhva never wrote a commentary on the Arthashastra and makes little to no mention of the text, there are similarities between the Arthashastra and its contribution to economics and social cohesion and Madhva's contribution to economics and social cohesion.

\section{Madhva's context}

In considering Madhva's contribution to social cohesion within the ambits of this article, it is important to understand the social and economic milieu in which Madhva found himself. From 1200 CE to 1350 CE was a formative time in Indian history. Apart from the rise of Madhva's Dvaita philosophy, India witnessed the establishment of Islam with the Delhi sultanate in 1200 CE. According to Singh (2018:82), the administration of the Delhi sultanate advanced 'IndoIslamic engineering' and 'expanded development rates in India's populace and economy'.

5.See the United Nations Human Settlements Programme (2011:9) 
Under the Delhi Sultanate, Madhva lived during the administration of the Mamluk (1206-1290) and Khilji (1290-1320) states. During this time, India witnessed major shifts in its social, political, and economic environment. Prasad (2011:113) notes that Madhva rose during a time when 'Hinduism would face extinction'.

The period that Madhva found himself in was a tumultuous and uncertain period for Hinduism and Indian society. Madhva's religious thought would not only transform the Hindu faith but also contribute to the broader, transforming Indian community at the time.

Madhva is believed to have been born and died in Udupi, a southern city in Karnataka in India. Although his hometown was in the southern regions of India, Madhva travelled to neighbouring cities and states. As he began to explore the foundations of what would become his Dvaita philosophical system of Vedanta, Madhva travelled far south and north to engage in debates where he is believed to have debased Shankara's Advaita Vedanta.

After exploring the southern cities of India, Madhva travelled to the northern cities of Haridwar, Badrinath and Varanasi where he engaged in more debates. Prasad (2011:43) notes that Madhva's travels and Dvaita philosophy came during an 'onslaught of Islamic powers'. The invasion by Islamic empires fostered a tense environment in India - one that Madhva could not escape.

The Mamluk dynasty (1206-1290) was the first dynasty that Madhva lived through. Mamluk is an Arabic term used to refer to a non-Arab slave who accepted Islam, subsequently being freed from slavery. The Mamluk dynasty is also referred to as the Slave dynasty, as the major rulers of this dynasty were of non-Arab, slave descent. Additionally, the Mamluk dynasty of the Delhi Sultanate were of Turkish and Afghan origins.

The Mamluk dynasty ended in 1290 when Jalauddin Khilji founded the Khilji dynasty. Jalauddin Khilji is revered as one of the strongest militant leaders of the Delhi sultanate as he kept the Mongol invasion at bay.

The following leaders of the Delhi sultanate ruled during Madhva's lifetime:

1. Razia (1236-1240) of the Mamluk dynasty. Razia Sultana is famous for being the first female Muslim ruler of India and for her invasion and conquest of Ranthambore. Much of Razia's reign focused on asserting her claim and authenticity as a ruler of the Delhi sultanate.

2. Ghiyas-ud-din Balban (1266-1287) of the Mamluk dynasty. Ghiyas-ud-din stressed the importance of allegiance to the crown and is known to have spied on members of his council and the general populous. He is also known for conquest of Mewat and Gwalior. Ghiyas-ud-din also introduced the Persian festival Navroz to India.

3. Jalauddin (1290-1296) of the Khilji dynasty. Jalauddin was the first ruler of the Khilji dynasty. He defended India from attacks by the Mongols, and made vital contributions to the growth of the Delhi sultanate and Islam.

4. Ala-ud-din (1296-1316) of the Khilji dynasty. Ala-ud-din is famous for his victories over the kingdoms of Gujarat, Chittor and Malwa. Ala-ud-din also implemented economic policies that directly affected the livelihood of Hindus. Kaur (2019:33) says: 'Alaudin Khilji was the greatest ruler of the Khilji dynasty and was the first Muslim ruler to extend his empire right up to the extreme South of India'. Ala-ud-din's reign made significant changes to the social, political, and economic state of all India, making him one of the most prominent rulers when reflecting on Madhva's context.

5. Shihab-ud-din Omar (05 January - April 1316) of the Khilji dynasty. Omar was the son of Ala-ud-din and ascended to the throne at the age of six. Very little is known of his reign which lasted four months before he died.

6. Qutb-ud-din Mubarak Shah (April 1316 - May 1320) of the Khilji dynasty. Shah was the last ruler of the Delhi sultanate to have reigned during the time of Madhva. Shah is famous for the abolishment of severe taxes and fines and made attempts to rectify the harsh treatment of Hindus that were set in place by Ala-ud-din.

Of the six rulers of the Delhi sultanate mentioned above, Ala-ud-din stands out as the most influential ruler. The socioeconomic reforms by Ala-ud-din affected India as a whole. Ala-ud-din's reforms transformed Hindu societies and directly affected Madhva's life as he travelled and resided in different Indian states that were subject to Ala-ud-din's rule. According to Kulke and Rothermund (2002):

Ala-ud-din's predecessors had based their rule mainly on the strength of their army and the control of a few important towns and fortresses. They derived their financial resources from loot, from taxes imposed on the markets of Delhi, from the land revenue of the area around Delhi and from the tribute of subjected kings. Land revenue and tribute were not always paid very regularly. The rural people were still mostly Hindus; the Muslims lived in the cities and towns.... (p. 160)

The Khilji dynasty ruled India through its strong armies and financial control. Ala-ud-din is believed to have said (see Kulke \& Rothermund 2002):

The Hindus will never become submissive and obedient till they are reduced to poverty. I have, therefore, given orders, that just sufficient shall be left to them from year to year, of corn, milk, and curds, but they shall not be allowed to accumulate hoards and property. (p. 164)

Like most colonial governments, a successful rule was based on the complete dominance of the livelihood of all citizens of the colony. The economic policies designed by Ala-ud-din were solely for the purpose of strengthening the Delhi sultanate at the expense of the Hindu community. Due to Ala-ud-din's economic policies, an economical divide formed between the Hindus in rural areas and the Hindus and Muslims living in the cities.

Klune (2014:1) notes that under the reign of Ala-ud-din, the Khilji dynasty engaged in 'less tolerant behaviour towards 
the Hindus, evidenced by the destruction of temples and heavier taxation'.

The intolerance of the Khilji dynasty to Hindus, the destruction of temples and strong taxation laws affected a society that Madhva was preaching to. Evidently, Madhva lived in a context that was plagued with war, illegitimate kings, and harsh living conditions for Hindus.

Having lived through the Mamluk and Khilji dynasty, Madhva was a first hand witness to the economic challenges faced by Hindu communities. To assess Madhva's contributions to economics and social cohesion, Madhva's writings are vital. Sri Madhvacharya was a prominent philosophical teacher who contributed to the Vedanta school of Hindu philosophy. Madhva is famous for his advocacy of the Dvaita (dualism) philosophy.

Hindu tradition places Madhva's birth at 1238 CE and death at 1317 CE. During his lifetime, Madhva wrote commentaries on the foundational texts of Hinduism and composed his own literary works to elaborate on his Dvaita philosophy. Madhva's Dvaita philosophy remains an important part of Vedanta philosophy and has a significant following in India and internationally.

\section{Madhva's literary works}

This section explores Madhva's literary works considering the six themes of the Arthashastra to assess Madhva's contribution to economics and social cohesion.

Having come after the great philosophers like Shankara and Ramanuja, Madhva saw fit to ensure that all his literature focused on expanding Dvaita philosophy while simultaneously offering a critique on Advaita and Visistadvaita. Despite finding himself in a context that required Hinduism's participation in social, economic, and political discourse, Madhva saw fit to write mainly on Dvaita philosophy.

Despite his dedication to Dvaita philosophy, Madhva makes certain notes that pertain to ethical behaviour that relates to the lessons in the Arthashastra. In the Tatparya Nirnaya (see Sonde 2011:69-228), Madhva says:

3.14-16. 'For householders, charity of wealth and for the forestdwellers charity of food (is recommended).

9.16-19. 'Sacrifice means renunciation of wealth etc. at the feet of the Lord.'

14.22-24. 'For the sake of wealth, of dear ones or those who are inimical or because of fright, there is never any decrease in their devotion to Sri Vishnu.'

18.6. 'In the sacrifice of wealth, in the sacrifice of knowledge, in the sacrifice of penance, one should perform charity, instruct and practice austerity according to one's capacity and according to the classification ....'

Madhva's commentary on the Tatparya Nirnaya says very little of economic and governmental policy. However,
Madhva speaks on acquiring, sharing and detachment from wealth for the sake of moksha and social welfare.

The focus of Madhva's thought on wealth rests on the importance of material possessions, the acquisition of material objects as establishing Dvaita, and indifference to wealth as one's focus must be on Vishnu.

In doing so, Madhva stresses that all actions performed should be for the delight of Vishnu. The delight of Vishnu is linked to detachment from material objects and performing actions that contribute to social welfare.

Contributing to economics and social cohesion, Madhva's Tatparya Nirnaya stresses the importance of indifference to the presence of wealth and the sharing of wealth for social welfare purposes. Sharma (1962:xii) attributes 37 literary works to Madhva. These writings comprise Madhva's commentaries on the Upanishads, Bhagavad Gita, Brahma Sutras, the Vedas, and other texts that expound his Dvaita philosophy.

Unlike the Arthashastra that focuses on economic policies and social/governmental reforms, Madhva's literary works focus solely on Dvaita philosophy, devotion to Vishnu, and a critique on Advaita and Visistadvaita. In this sense Madhva contributes very little to economic policies and governmental structures. Despite the lack of noteworthy contributions to economic policies, Madhva's thought on Karma yoga contributes to understanding work ethic and detachment from material objects. Positive work ethic and detachment contribute to economic development by ensuring that all members of a community make valuable, selfless contributions to the development of their community.

\section{Arthashastra and Madhva's contribution to economics}

Diplomacy, social structures, and ethics are important themes in the Arthashastra. Shabbir (2004:1) describes the following as valuable lessons in the Arthashastra:

1. Sandhi: the accommodation of all people, irrespective of status or nationality.

2. Vigraha: viewing all people as equal and removing all sense of hostility so that war and conflict can come to an end.

3. Asana: state of being indifferent in treatment or understanding to different kingdoms or governmental structures.

4. Dvaidhibhava: the promotion of peace and harmony through policies and treaties with different kingdoms.

5. Samsarya: protecting weaker kingdoms and tribes from mutual threats.

6. Yana: intervening with other kingdoms when there is an unjust king. Although conflict is frowned upon, war is necessary in the case of removing an unjust king. 
Other concepts in the Arthashastra mentioned by Shabbir (2004:1) are that of effective usage of power, promotion of welfare, honesty, truthfulness, and self-discipline.

The above-mentioned lessons of the Arthashastra are solely for the purpose of economic development and social cohesion. Dvaidhibhava, Samsarya and Yana relate to economic and administrative management, while Sandhi, Vigraha and Asana focus on social engagements with culturally and economically diverse people.

In addition to the six lessons, honesty, self-discipline, and effective usage of power contribute to transparent, successful governance and cohesive social engagements. While Madhva does not directly speak on economics and governmental administration, his commentary on the Bhagavad Gita and Tatparya Nirnaya mirror the lessons of the Arthashastra on economic development and social cohesion.

On Bhagavad Gita 9.9 (see Sonde 2011:143) Madhva comments: '...He who creates and destroys the universe effortlessly, how can there be any attachment to in His actions....' Madhva asserts that Vishnu is the controller of the universe and therefore, all things within the material world belong to Vishnu. Because all things belong to Vishnu, one should be indifferent to changes in the world as they are beyond the control of the mortals.

Madhva adds to this in Gita 6.4 (see Sonde 2011):

'Sri Krishna speaks of the marks of those who have established themselves in equanimity. For such one, there is comprehensive detachment.' (p. 106)

The term equanimity is used by Madhva to denote a sense of calmness and indifference to pressure. Madhva teaches that equanimity comes with detachment. When one is detached from the thoughts and objects related to the material world, changes within the material world does not deter the focus of one's mind.

Through self-discipline, one can attain and maintain detachment, resulting in equanimity and composure. Relating to the Arthashastra, Madhva's thought on detachment and equanimity engage the points of indifference, self-discipline, and mental welfare.

Madhva's thought on war revolves around his notes in his invocation to the Tatparya Nirnaya (see Sonde 2011:4). Madhva says:

'But if you do not fight such righteous battle, then shorn of one's righteous duty and glory you will incur demerit.'

'Preferable is one's own ordained Dharma (perennial principle) even though imperfect, thern following Dharma ordained for others even though followed perfectly. Death in performance of one's own Dharma is preferable for the Dharma ordained for others is fraught with danger.'

The other literary work of Madhva agrees that, on the topic of war, one must strictly adhere to Dharma. Madhva stresses the importance of following one's duty and performing all prescribed action to avoid the accrual of demerits and punishment.

In Gita 17:1 (Sonde 2011:219) Madhva notes that 'the Vedas is Dharma and all that is contrary to that is against Dharma'. Therefore, war as prescribed action that upholds Dharma (as defined in the Vedas), is action that must be performed.

Madhva endorses war that is prescribed by Dharma and for the preservation of Dharma. Madhva's understanding of the Vedas as Dharma suggests that the Vedas (and texts affiliated to it, such as Upanishads, Brahma Sutras and Bhagavad Gita) are the epitome of righteousness that teaches cosmic wellbeing.

Madhva's thoughts on warfare align itself with the lesson of the Arthashastra on Dharmic (or righteous) war and protecting the weak. This is evident in Madhva's understanding of righteous war (war for the protection of Dharma) as ordained action prescribed by Vishnu.

In Gita 1.40-41 (Sonde 2011:37) Madhva engages the concept of truthfulness by commenting on the discussion between Arjuna and Sri Krishna. Madhva acknowledges Arjuna's confusion on the differences in advice that he was given. In explaining how Arjuna should engage all opinions given to him, Madhva says that all opinions that are truthful are united.

Madhva encourages truthfulness and describes it as an attribute worthy of moksha. To be truthful is to reflect deep devotion and dedication to the will of Vishnu. Madhva also posits that truthfulness stems from detached action, as one lies in pursuit of materialistic objects.

Madhva's thought on peace relates to his idea of detachment. Throughout Madhva's literary works and philosophical ideologies, he stresses the importance of detachment. According to Madhva, detachment from materialistic objects is an imperative for a person who desires to attain moksha. Madhva encourages detachment from materialistic objects as one's focus should only be on the will and delight of Vishnu.

\section{In Tatparya Nirnaya 2.15 (Sonde 2011:15), Madhva says:}

' $[H]$ e without attachment to sense, does not grieve. He remains quiet and peaceful within. Being attached to the body, every one becomes influenced by sorrows.'

\section{Madhva adds to this in Gita 1.66 (Sonde 2011:55):}

'For the one who has no concentration, his intellect can never have realization. Therefore, it is declared that peace is not for the one without concentration. Peace means deliverance, Peace, Deliverance, Nirvana have similar meanings, thus has it been said.'

For Madhva, peace comes from concentration. By concentrating on Vishnu, one can attain inner peace. Madhva describes this inner peace synonymously with deliverance and Nirvana. To 
concentrate on Vishnu and attain inner peace, Madhva stresses the detachment from sensory organs. Therefore, his understanding of peace and detachment are interlinked.

Madhva's context shows that he was aware of the Islamic forces pervading in India. Sarma (2008:1) agrees that there were strong Islamic influences during Madhva's time, but also suggests the presence of Christianity within Madhva's context. Sarma (2008:6) notes that one of the misconceptions of Madhva is that 'Madhvacarya is Christ rather than that he is like Christ'.

The presence of Islam, Christianity, and the variety of Hindu beliefs in Madhva's context suggests that Madhva taught in a community that required teachings of cohesion and religious tolerance. In alignment with the Arthashastra, Madhva's commentary on Bhagavad Gita 6.9 Sonde (2011:109) teaches:

'One who is affectionate without any expectation is the magnanimous one. Seeing suffering the one who extends help is the friend. One who causes pain is evil. One who does not reciprocate friendship even when given friendship is ungrateful. One who does good to others only if good was done for them is known as mediocre...'

On the lesson of accommodation and harmony in the Arthashastra, Madhva proposes friendship as affectionate actions that promote social harmony and peace. Madhva describes one who hurts (or causes pain and discomfort) others as evil. As a result, Madhva promotes selfless acts that seek to alleviate pain and promote friendship. Therefore, promoting harmony and the accommodation of other members of society by looking beyond divisive tools, with the goal being to promote friendship.

Madhva's thoughts on peace, honesty, and harmony are linked to his emphasis of detachment. In turn, detachment requires self-discipline to focus the mind only on performing actions that please Vishnu.

On Kautilya, Howladar (2017:78) states:

Kautilya is perhaps less well known outside India compared to other social and political philosophers of the world like Confucius and Machiavelli, but is definitely considered to be the first genuine political theorist in Indian history. (p. 78)

Madhva, however, is described by Subindra Rao (2019:3) as the 'first historical teacher of the Dvaita doctrine.'

Kautilya as a political minister living around $300 \mathrm{BCE}$ and Madhva as a philosophical teacher in 1200 CE - 1317 CE, served different purposes to different contexts. Where Kautilya's contribution was that of economic policy, political legislation for state operations and successful governance, Madhva's contribution was that of Dvaita philosophy.

Kautilya's focus was on shaping a government that had the interest of the people (their economic and social welfare) at heart. Madhva's focus was that of criticising Shankara and Ramanuja in order to establish Dvaita philosophy.
As a philosophical teacher establishing a new Vedantic school of thought, Madhva did not see fit to dedicate time to writing economic policy or governmental legislature. His contribution to economics is not on the legal level of Kautilya and his Arthashastra. Instead, Madhva contributes to economics by promoting pro-social behaviour.

Madhva's contributions to economics and social cohesion align with the Arthashastra and are embedded in his commentary of the Bhagavad Gita and Tatparya Nirnaya.

His contributions, as aligned with the Arthashastra, are contained in the following lessons:

1. Detachment: Madhva believed that by detaching oneself from the material world, one can attain a state of equanimity and be indifferent to sudden change or pressure. The state of equanimity allows for calmness in tense situations and is a vital skill for leaders in economic and governmental spaces. Madhva's detachment mirrors the lesson of Asana.

2. Performance of one's duty: According to Madhva, the performance of one's duty to society is imperative and should be a top priority. In terms of economic management, Madhva teaches that one must detach from performing actions that are for selfish purposes and rather perform actions that are aligned with Dharma contributing to social welfare. As a result, Madhva reiterates the lessons of Samsarya and Yana.

3. Truthfulness: Being truthful is an ethical practice that is of top priority in economic management spaces. Deceitfulness results in corrupt management of funds that profit a select few, at the expense of the vast majority.

4. Self-discipline: Madhva's comments on self-discipline are applicable to any field. It is always important to concentrate the mind of completing a task successfully without easily being distracted. Considering the Arthashastra, Madhva suggests self-discipline as a practice that guides ministers and kings to always remember the interests of the people. Leaders of a governmental structure must be self-disciplined in putting the interests of the people above everything else.

5. Friendship: the concept of friendship in Madhva's philosophy is for the purpose of alleviating pain and performing selfless acts of kindness. Madhva proposes friendship to advance social welfare and promote cohesion through selfless acts of support. Madhva's thought on friendship promote the lessons of Dvaidhibhava, Vigraha and Sandhi.

The above-mentioned lessons from Madhva's commentaries align with the Arthashastra in promoting sustainable economic development and social cohesion.

\section{Madhva and economics}

On Indian economy Paruchuru, Mavuri and Jyothsna (2020) state: 
The present performance of Indian economy, partly supported by International Monetary Fund (IMF) estimation of India being one of the fastest growing economies in the World, played an important role. Despite the predictions, surprisingly the economy has not fared well since in the last quarter of 2018-19 (5.8\%) indicating a slowdown in the economy. The July 2019 monthly report released by the Union Finance Ministry reveals a three-year trend of 1 declining economic growth. It is a clear picture of India's underwhelming economic performance for a decade. Further it highlights about slowdown in agricultural output, sluggish investment consumption ration, increasing inflation and deficit balance of payments in the current account. Hence it is a story of what could have been, of growth that did not happen, of missed opportunity. It also narrated the story of mismatch of Economic and Political objectives. (p. 169)

Despite the above-mentioned critique, in March 2021 CNN Business ${ }^{6}$ notes that after India's recession, its gross domestic product could expand by $12.6 \%$ in 2021 and that:

If that level of growth is realized, it would allow India to reclaim its status as the fastest growing major economy ... (n.p.)

Considering some setbacks and the possibility of India becoming the fastest growing major economy, Panagariya and Mukim (2014:20-21) claim that of the 17 largest states of India, $29.9 \%$ of people live in poverty.

Panagariya and Mukim (2014:20-21) suggest that while poverty in India is on a steady decline, there is still room for improvement. This means that, until poverty is completely removed from the Indian society, there will always be more that can be done. This validates the need for economic development.

Madhva's contribution to economic development is based on his comments of detachment, honesty, and friendship. His contributions are more philosophical and ethical rather than legislative.

Neumark (2017:748) explains that 'detachment is an ethical practice' is best understood as a 'care for relationships'. Neumark (2017:748) suggests that detachment from material objects linked to selfish motives displays a sense of care and love for other members of society and the relationships thereof.

Cross (2011:36) supports detachment in economic spaces by suggesting the following:

1. There is emerging interest among anthropologists in 'disconnection, distance, and detachment' as meaningful frameworks for action and forms of virtue.

2. [S]ee detachment as a relationship, or as relational.

3. [D]etachment is a guide to conduct, it is an ethic.

4. Detachment as a corporate ethic is one that must be constantly performed in the everyday operations of management.

6.See https://www.cnn.com/2021/03/19/economy/oecd-economic-outlook/index html
Evidently, detachment in corporate spaces is an imperative for successful working relationships.

Honesty in economic spaces is one such topic that requires little elaboration as honesty is, or should be, an ethical prerequisite for all persons dealing with finances and economic legislation. Failure to be honest results in the failure to be transparent. The failure to be honest and transparent is often due to corrupt actions for selfish purposes.

Hugh-Jones (2016:1-2) suggests that with honesty comes mutual trust, which in turn promotes trade and cooperation. Additionally, Hugh-Jones (2016) states:

When people are honest, bare promises act like contracts, allowing gains from cooperation in situations where formal contracts would be hard to write or enforce. (p. 1)

Mazar (2006:12) adds that dishonest action is linked to selfish behaviour (antisocial behaviour) and honesty is linked to detachment from motives of self-gain (prosocial behaviour). Honesty as prosocial behaviour promotes strong relationships, thus fostering positive business relationships and economic development.

Madhva's contribution to economic development through his teachings of honesty laid the foundation for friendships, another contribution to economic development and social cohesion.

According to Nunez (2004:2), the divide between the rich and the poor causes social division through classism. An important part of economic development is social cohesion on the grounds of closing the gap between the rich and the poor. Madhva's contribution to this discussion is evident in his comments of friendship.

D'hont, Doern, and Delgado Garcia (2016:528-540) support Madhva by noting the following:

1. [F]riendship ties are governed by accepted rules of behaviour such as equality, benevolence or reciprocity.

2. Entrepreneurs reported that strong friendship ties played a role in achieving consensus and overcoming conflict in decision-making processes.

3. [S]trong friendship ties seemed to favour affective associations - i.e., the selection of partners from personal networks based on the quality of friendship ties...

Evidently, friendship plays an important role in the formation of business relationships and in the decision-making process of businesses. Madhva's thoughts on friendship as performing selfless actions that alleviate pain promotes business relationships centred on healthy relationships, which thus contribute to economic development in poor communities.

Reflecting on the current business world and economic scholars, Madhva's thoughts on detachment, honesty and 
friendship contribute to economic development and social cohesion.

\section{Conclusion}

Any discussion on economics requires mention of the Arthashastra. The Arthashastra makes valuable contributions to economic development and social cohesion as it is a legislative document written by Kautilya.

Unlike Kautilya, Madhva was a philosophical teacher whose attention was focused on contributing to Vedantic philosophy through the establishment of his Dvaita philosophy. As a philosophical teacher, Madhva dedicated his literary works to exploring the nature and non-duality of Atman and Brahman.

Although Madhva's focus was on Dvaita philosophy, he made major contributions to ethical behaviour. Applying Madhva's ethical lessons to the Arthashastra allowed this article to understand Madhva's contribution to economic development and social cohesion.

Through his lessons on detachment, Madhva promotes economic development by encouraging members of society to detach from selfish acts. The detachment from selfish acts allows for economic development as members of society are encouraged to focus on contributing to social welfare rather than performing selfishly motivated actions.

Honesty allows for transparency and accountability. Additionally, honesty contributes to mutual trust, an important contributor to business relationships. Madhva's thought on honesty links to his notes on friendship. In the economic sector, friendship allows for the formation of business relationships and better decision-making processes. Through honesty and friendship, cohesion is promoted among different individuals.

Madhva's thought on detachment, honesty and friendship promote cohesive working relations that centre on social welfare by contributing to economic development in poor communities and bridging the gap between the rich and the poor. Taking Madhva's context into consideration, Madhva looks beyond religious divides and offers his lessons on detachment, honesty, and friendship as the foundation for unity, economic development, and cohesion.

In a world that is divided by religion and classism, Madhva teaches that social welfare should be the ground on which people unify. Applying Madhva's lessons to the current economic world means that all members of society are encouraged to contribute to the advancement of society.

\section{Acknowledgements Competing interests}

The authors declare that they have no financial or personal relationships that may have inappropriately influenced them in writing this article.

\section{Authors' contributions}

M.Y.S. conceptualised and visualised the crux of the article and wrote the first draft. M.S. supervised the draft, and developed the methodology and formal analysis. Both authors reviewed and edited the final draft.

\section{Ethical considerations}

This article followed all ethical standards for research without direct contact with human or animal subjects.

\section{Funding information}

This research received no specific grant from any funding agency in the public, commercial or not-for-profit sectors.

\section{Data availability}

Data sharing is not applicable to this article as no new data were created or analysed in this study.

\section{Disclaimer}

The views and opinions expressed in this article are those of the authors and do not necessarily reflect the official policy or position of any affiliated agency of the authors.

\section{References}

Barker, T., 1977, 'International trade and economic growth: an alternative to the neoclassical approach', Cambridge Journal of Economics 1, 153-172.

Boesche, R., 2003, 'Kautilya's Arthasastra on war and diplomacy in Ancient India', The Journal of Military History 67(1), 9-38. https://doi.org/10.1353/jmh.2003.0006

Borisov, I.V. \& Vinogradov, S., 2018, 'The role of social cohesion in social and economic processes', in Business and management sciences: New challenges in theory and practice, pp. 521-539, Gödöllő, Szent István University.

Cross, J., 2011, 'Detachment as a corporate ethic: Materializing CSR in the diamond supply chain', Focaal-Journal of Global and Historical Anthropology (60), 34-46. $\mathrm{https}: / /$ doi.org/10.3167/fcl.2011.600104

D'hont, L.D., Doern, R. \& Delgado Garcia, J.B., 2016, 'The role of friendship in the formation and development of entrepreneurial teams and ventures', Journal of Small Business and Enterprise Development 23(2), 528-561. https://doi. org/10.1108/JSBED-02-2015-0027

Howladar, M., 2017, 'Political thoughts of Kautilay: An overview', International Journal of Multidisciplinary Research and Development 4(3), 78-80.

Hugh-Jones, D., 2016, 'Honesty, beliefs about honesty, and economic growth in 15 countries', Journal of Economic Behavior \& Organization 127, 1-32. https://doi. org/10.1016/j.jebo.2016.04.012

Kaur, J., 2019, 'Character and achievements of Alauddin Khilji', International Journal of History 1(1), 33-34.

Klune, C., 2014, The Delhi Sultanate's treatment of Hindus, viewed 12 April 2021, from https://www.e-ir.info/2014/02/11/the-delhi-sultanates-treatment-of-hindus/.

Kraipornsak, P., 2018, 'Good governance and economic growth: an investigation of Thailand and selected Asian countries', Eurasian Journal of Economics and Finance 6(1), 93-106.

Kulke, H.R. \& Rothermund, D., 2002, A history of India, 3rd edn., Taylor and Francis e-Library, New York, NY.

Macek, R., 2014, 'The impact of taxation on economic growth: case study of OECD countries', Review of Economic Perspectives 14(4), 309-328.

Mazar, N.A., 2006, 'Dishonesty in everyday life and its policy implications', American Marketing Association 25(1), 2-21. https://doi.org/10.1509/ jppm.25.1.117

Neumark, T., 2017, “'A good neighbour is not one that gives": Detachment, ethics, and the relational self in Kenya', Journal of the Royal Anthropological Institute 23(4), 748-764. https://doi.org/10.1111/1467-9655.12699

Nunez, J.G., 2004, Classism, discrimination and meritocrascy in the labor market: The case of Chile, University of Chile, Chile.

Panagariya, A.M. \& Mukim, M., 2014, 'A comprehensive analysis of poverty in India', Asian Development Review 31(1), 1-52. https://doi.org/10.1162/ ADEV_a_00021 
Paruchuru, M., Mavuri, S. \& Jyothsna, M., 2020, 'Challenges for economic growth in India - A critique', Journal of Critical Reviews 7(7), 169-175.

Prasad, M.N., 2011, Three Acaryas and Narayana Guru, DK Printworld, Verkala.

Rajeev, R., 2012, 'Kautilya's views on origin and nature of state in Arthasastra', International Journal of Computing and Corporate Research 2(1), 1-34.

Republic of South Africa, 1997, Principles, guidelines, recommendations, proposed policies and programmes for developmental social welfare in South Africa, White Paper for Social Welfare, Department of Welfare, viewed n.d., from https://www. gov.za/sites/default/files/gcis_document/201409/whitepaperonsocialwelfare0.pdf.

Ritzen, J.W. \& Woolcock, M., 2000, 'Social cohesion, public policy, and economic growth: Implications for countries in transition', in Annual Bank conference on development economics, pp. 2-33, World Bank, Paris.

Sarma, D., 2000, 'Is Jesus a Hindu? S.C. Vasu and multiple Madhva misrepresentations', Journal of Hindu-Christian Studies 13(8), 1-7. https://doi.org/10.7825/21646279.1228

Shabbir, S., 2004, Kautilya on leadership: Lessons from Arthashastra, Aligarh Muslim University, Aligarh.

Sharma, B.N., 1962, Philosophy of Sri Madhvacarya, Bharatiya Vidya Bhavan, Bombay

Sharma, S., 2008, 'Purusharthas-aims of life', in National seminar on Indian philosophy: It's relevance in the 21st century, pp. 70-72, VPM's Joshi-bedekar College of Arts and Commerce, 18-19th January.

Sihag, S.B., 2016, 'Kautilya's Arthashastra: A recognizable source of the wealth of nations', Theoretical Economics Letters 6(1), 59-67. http://dx.doi.org/10.4236/ tel.2016.61008
Singh, A., 2018, 'Origin and ruling period of Delhi sultanate', International Journal of Academic Research and Development 3(2), 83-86.

Sonde, N., 2011, Sri Madhvacharya Bhashya and Tatparya Nirnaya on Bhagavad Gita, Nagesh D. Sonde, Mumbai.

Subindra Rao, A., 2019, Of deities and demons: Madhva's doctrine of hierarchy in the Mahabharatatatparyanirnaya, University of Calgary, Calgary.

Suwandaru, A.A., 2021, 'Empiricial analysis on public expenditure for education and economic growth: Evidence from Indonesia', MDPI Economies 9(146), 1-13. https://doi.org/10.3390/economies9040146

Tanwar, R., 2014, 'An analytical study of the relevance of Arthashastra in modern India', IOSR Journal of Economics and Finance 5(3), 32-35. https://doi. org/10.9790/5933-0533235

Trautmann, T.R., 2012, Arthashastra: The science of wealth, intr. Das, Penguin Books Ltd, New Delhi.

United Nations Human Settlements Programme, 2011, Infrastructure for economic development and poverty reduction in Africa, viewed n.d, from https://unhabitat. $\mathrm{org} / \mathrm{sites} /$ default/files/download-manager-files/Infrastructure\%20for $\% 20$ Poverty\%20Reduction\%20and\%20Economic\%20Development\%20in\%20Africa. pdf.

Waldauer, C., Zahka, W. \& Pal, S., 1996, 'Kautilya's Arthashastra: A neglected precursor to classical economics', Indian Economic Review 31(1), new series, 101-108, viewed 10 June 2021, from http://www.jstor.org/stable/29793735

World Bank, 1994, Infrastructure for development, World Development Report, Oxford University Press, New York, NY. 